Paudel, U. R., \& Devkota, N. (2020). Harmonization of socioeconomic policy

and institutional set-up for efficient operation on Nepal-India open border small

business. Journal of International Studies, 13(1), 108-122. doi:10.14254/2071-

8330.2020/13-1/7

\title{
Harmonization of socioeconomic policy and institutional set-up for efficient operation on Nepal-India open border small business
}

\author{
Udaya Raj Paudel \\ Quest International College, Pokhara University \\ Lalitpur, Nepal \\ udayapaudel7@gmail.com
}

ORCID 0000-0002-5234-5081

\author{
Niranjan Devkota \\ Quest International College, Pokhara University \\ Lalitpur, Nepal \\ niranjandevkota@gmail.com
}

ORCID 0000-0001-9989-0397

Abstract. Open border extrapolates interlinking and ample opportunities among the countries but that requires a substantial amount of policy learning and readiness of the people for economic transformation. A long-term tradition of free movement of people across borders can be witnessed globally but developing, operating, sustaining and institutionalizing cross-border cooperation and harmonization remain to be great challenges. In such a context, this research delves into the issue of cross-border small business activities between NepalIndia open border regions at the level of socioeconomic policy harmonization and institutional set-up convenient for policy implications. The study shows that the issue of small businesses in Nepal-India open border is neither adequately addressed, nor harmonized and institutionalized. So, the priority of Nepal-India small business activities in the border regions should reside on the perception of people, harmony, trust, trade relation and international brotherhood for growth, and systematization. Thus, from the spirit of free movements of people and commodities enshrined in the 1950 Treaty of Peace and Friendship to the present; governance, harmonizing and institutionalizing processes in NepalIndia cross-border small business are complex endeavors.

Keywords: harmonization, Nepal-India open border, small business, socioeconomic policy, institutional set-up.

JEL Classification: F50, G41, G18, O53, Z13 


\section{INTRODUCTION}

Small businesses in open border areas are common but sensitive and uncertain (Houtum, 2000; Paudyal, 2014 and Paudel \& Devkota, 2018). Although a long tradition of free movement of people across borders can be witnessed globally; developing, operating and sustaining institutionalized cross-border cooperation and harmonization remain vital primarily on American borders (Scott, 1999 and Covarrubias, 2017), in the borders of the Euro-zone (Schack, 1999; Stojkov \& Nikolov, 2008; Kramar, 2011; and Pangalos, Salmatzidis \& Pagkalos, 2014), among African bordering nations (Minde \& Nakhumwa, 1998; Macamo,1999; Lesser \& Moise-Leeman, 2009; Ogalo, 2010; Afrika \& Ajumbo, 2012; Ayadi, Benjamin, Bensassi \& Raballand, 2013 and Kuepie, Tenikue \& Walther, 2016), and at the borders of Asian nations too (Behera, 2011; Kavitha, 2016; Azmi, Hamid, Ahmad \& Ramli, 2017), including Nepal-India border (Pant, 1962; Baral, 1992; Subedi, 1994; Shrestha, 2003; Sharma \& Thapa, 2013; Paudyal, 2014; Adhikari, 2015 and Paudel et al., 2018) as well as in the global scenario (Walther, 2014 and Sevensson, 2015).

Thus, crossborder cooperation is becoming an increasingly important factor (Stojkov \& Nikolov, 2008 and Setnikar et al., 2014) having nexus to socio-eco-cultural sharing between the people residing in border areas (Anderson \& Wever, 2003; Andersen \& Foss, 2005; Velde \& Van Naerssen, 2011; Afrika \& Ajumbo, 2012; Walther, 2014; Chelariu \& Osmonbekov, 2014; Boellis, Mariotti, Minichilli \& Piscitello, 2016; Azmi et al., 2017; Bensassi et al., 2016 and Decoville \& Durand, 2018). The multi-contextual characters of border regions pose challenges for the concerned governments in part of sustained wellfunctioning (Schack, 1999; Houtum, 2000; Kumar, 2013; Szekely, 2013; Paudyal, 2014; Svensson, 2015; Kavitha, 2016 and Covarrubias, 2017) borders and cross-border small-scale trading. Small business development has been identified by many experts as the key to economic success in a cross-country comparison (Kot et al., 2016). Open borders facilitate cultural continuity through interaction between the countries, having socio-religious affinity (Pattanaik, 1998; Paudel \& Devkota, 2018). In Europe, a large number of crossborder partnerships have emerged, grown and sustained (Dutta, 2010). The DutchGerman border region is one of the classic examples that has a long tradition of institutional cooperation which has contributed to stable and open borders and daily cross-border practices (Szytniewski et al., 2017).

In the context of Nepal-India, an intense people-to-people unique relationship of business, friendship in multiple facets and cooperation also has direct relation to open borders (Pant, 1962; Baral, 1992; Kanshakar, 2001; Jha, 2013; Paudyal, 2014; Paudel et al., 2018) maintaining coherence among Nepali and Indian people in terms of lifestyle, business operation, ways of thinking, motivation, dream and happiness, history, culture, treaties, political movements and policies (Baral, 1992; Subedi, 1994; Kansakar, 2001; Shrestha, 2003; Jha, 2013 and Paudel \& Devkota, 2018). Border small business of Nepal-India en route trade since the 1950's Treaty between Nepal and India to the present has further expanded and stimulated the cross-flow of commodities like garments, raw materials, manufacturing goods, medicines and daily consumer goods (Kanshakar, 2001; Jha, 2013 and Paudel et. al., 2018). Small businesses in the border areas are functioning under tax evasion while their goods are transported further to major cities and the capitals (Fuest \& Riedel, 2010). This affects national revenues (Paudel \& Devkota, 2018) and increases informal business practices (Fuest \& Riedel, 2010).

Vast volumes of literature on the Nepal-India border issues (Kansakar, 2001; Jha, 2013 and Paudel et. al., 2018) focus mainly on people and their relationship. (Pant, 1962; Baral, 1992; Kansakar, 2001; Jha, 2013; and Paudel et al., 2018) analyze the trends of Nepal-India trade relation in their socio-cultural and economic cross-sectional analysis from the customer and small business perspectives. Subedi (1994) advises to revisit the 1950's Treaty, Shrestha (2003) analyzes bilateral trade relation, Behera (2011) and Sharma \& Thapa (2013) focus on migration and security, Kumar (2013) highlights the mutual needs of 
people on both side, (Paudyal, 2014 and Adhikari, 2015) study the historical, architectural and cultural aspects of the subject matter, and Kavitha (2016) highlights problems and prospects of open border development in the region in question. Most of these and other studies argued that open borderss have proved to be beneficial in terms of socio-cultural ties, economic interdependence, and unique bilateral relation between both India and Nepal (Szytniewski et al., 2017).

Despite the fact that the available studies have focused on socio-eco-political and cultural aspects, they are not adequate enough to formulate policies on open-border business between Nepal-India borders (Paudel et al., 2018; Paudel \& Devkota, 2018). The study possesses high value, for Nepal lies between China and India, and these two giant economies of Asia are the concern for America and many global financial institutions and diplomatic organizations in part of their business policies and struggle for supremacy. Hence, Nepal-India cross border business issues require comprehensive study for further institutional set-up and harmonization.

\section{LITERATURE REVIEW}

\subsection{A theoretical debate on open-border small business practices}

Small businesses in the Nepal-India open border is affected by social, economic, political and cultural variables. There are limited theories in the border issues and only some of the foremost ones are discussed in the paper. Houtum (2000) enlists three theoretical approaches: the flow approach, the cross border cooperation approach and the people approach related to open border business practices.

The flow approach theory focuses on the physical flow of goods, services and people across the border. It takes border as an artificial barrier and restriction is considered as loss. The governments from the center can inadequately address the border in the periphery. So, obstacles like border blockade even for the short period of time results in significant loss (Houtum, 2000; Anderson \& Wever, 2003; Davis, Faberman \& Haltiwanger, 2006 and Decoville \& Durand, 2018). Second, the cross-border cooperation approach theory emphasizes on cross-border cooperation. There is significance of cross-border cooperation for boosting economic growth, coherent activities of government and harmonizing socioeconomic activities (Kolk \& Margineantu, 2009; Kramer, 2011; Tkachenko \& Pustova, 2014; Kuzmin \& Kravchenko; 2014). Finally, the people approach theory concentrates in the socialization process. The orientation to time, activities, circumstances, language and culture play vital roles in existence of border (Reisinger, 2009). It is not limited to border as just lines in space. Yet, racial, religious, linguistic and cultural identities also act as separators and in the process of otherization (Houtum, 2000, Anderson \& Wever, 2003, Van der Velde \& van Naerssen, 2011 and Decoville \& Durand, 2018).

All the absorbed theories in this research focus on economic flow in relation to socio-eco-cultural factors and intense forms of cooperation. People, culture, perception and behavior are emphasized (Houtum, 2000, Anderson \& Wever, 2003) in all approaches. These border phenomena also can be categorized as Transaction Cost Approach (Williamson, 1975, 1979 and 1981), International Network Approach developed by some Swedish researchers in industrial marketing and international business in 1982, and Psychic Distance Approach (Johanson \& Vahlne, 1990).

The transaction cost approach theory puts emphasis on enhanced cost, communication and culture. It claims that individuals and family businesses when become successful, they cross the border, hence, big enterprises are not generally driven by individuals when they grow and cross the borders. It does not deal with physical flow of goods, people and services like in the flow approach theory (Paudel et. al., 2018).

Additionally, the international network approach theory emphasizes on the power of network in business. It believes that cross border cooperation can boost the development in the neighboring 
countries. It is because when new government is formed, they try to maintain good neighborhood and foreign relations for smooth functioning of the government and for aids for sustainability, budget and international communities' support, and for development (Scott, 1999, Velde \& Houtum, 2003; Anderson \& Wever, 2003; Kolk \& Margineantu; 2009, Kramer, 2011; Kuzmin \& Kravchenko, 2014, Tkachenko \& Pustova, 2014; Slausarciuc, 2015; Decovelle \& Durand, 2018). Thus, the more, better and intense the relation, the easier it is to maintain the trade and business in relation to nations. Finally, Psychic distance approach theory believes that it is not the matter of kilometers but the psychological proximity of the people that determines the business. According to this theory companies first tend to involve business with the country and people they understand and gradually increase their familiarities to the acquaintances and expand businesses. Cultural differences act as negative stereotyping and doubt but affinities of language, culture, customs and creeds connect people ultimately closer for performing business (Velde \& Houtum, 2003; Reisinger, 2009; Van der Velde \& Naerssen, 2011; Jackson, 2014; Decoville \& Durand, 2018).

The theory claims-the more the psychic distances the lesser the chance to venture the businesses. In other words, geographical proximity does not determine business but the psychological closeness. The examples of Switzerland and Germany, and China and Taiwan support this claim. Switzerland and Germany lie closer than China and Taiwan but do not have many businesses due to psychological distance; however, China and Taiwan are in greater geographical distance but collaborate many businesses due to psychological proximity. Taking impetus from these theories it can be concluded that Nepal and India can collaborate unlimited business due to intense people-to-people relation and socio-eco-cultural and psychological proximity (Anderson \& Wever, 2003; Szekely, 2013; Setnikar et al., 2014 and Covarrubias, 2017).

\subsection{Nepal-India business relationship: A critical view point}

Nepal geographically lies between $26^{\circ}$ and $31^{\circ} \mathrm{N}$ latitudes and $80^{\circ}$ and $89^{\circ} \mathrm{E}$ longitudes. Located in the continent of Asia, Nepal is a sovereign, independent, federal democratic and land-linked country between China in the North and East, West and South of India (Paudyal, 2014). With 1, 47,181 square kilometers total area, the country is divided into 3 main geographical regions: Himalayan, Hilly and Terai. The population in Nepal-India border is dependent on agriculture. Paddy, wheat, maize, cereals and cash crops are the main farming products in the bordering region (Paudel et al., 2018). Before 1990, Nepal used to export rice to India and other nations while the situation is topsy-turvy at the present (Shrestha, 2003). Nepal depends on India for goods transport facilities including marine access. There are 22 agreed transit and custom posts along the Nepal India border (Kanshakar, 2001). Among them, Sunauli - India/Nepal border is one of the important entry points. Nepal is located between two Asian giant economy China and India (Paudyal, 2014 and Kavitha, 2016). Nepal shares 768 miles border with Chinese territory and in the North while 1089 miles to India in the East, West and South (Jha, 2013). Based on the geographical proximity and access, Nepal has greater connectivity to India with 22 official checkpoints whereas China has only 6 official ports, which even do not function as intense and smooth as Indian checkpoints (Kansakar, 2001). It is because Northern part of Nepal contains mountain ranges covered with snow throughout the year, hence, rather inaccessible compared to border connectivity posts with India. 
Nepal has signed the first Treaty in 1792 with the East Indian Company ${ }^{1}$, the treaty agreed to pay equal tariff on both export and import through Indian territory (Nayak, 2010). However, only after the 1860, the boundary between both the countries was more or less stabilized (Pattanaik, 1998). Only in 1923, colonial British Government formally recognized Nepal as a sovereign independent nation and led border open to Nepalese citizen and for Indian merchants (Pattanaik, 1998). During colonial times in India, the British had an interest in keeping the border open for two reasons - first, impressed by Gurkhas, to recruit them into India army, and the second is Nepal was seen as a market for finished goods from India, which later Indian government followed (Das, 2008). Whatsoever the reason, it is evident that India and Nepal have shared intense people-to-people relation for long time (Kansakar, 2001) due to its geographical, cultural, religious, ethnic and economic affinities between the inhabitants of both sides across the border (Kumar, 2013). However, this relocation has not been witnessed in the past spirit in the recent activities between Nepal-India border region. The present government of Nepal has to emphasize on mitigating differences.

In 1950, India-Nepal Treaty for Peace and Friendship marks the framework for the unique ties between the two countries (Paudel \& Devkota, 2018). The treaty declares the open border between two nations that allows free movement of the people and commodities across the border, which has contributed significantly towards the activities of the people of two nations and relationship (Kumar, 2013 and Kavitha, 2016). Many studies including Kansakar (2001), Nayak (2010) and Jha (2013) highlight the 1950 treaty as an objective to strengthen the relationship between two countries by recognizing historical values and perpetuating peace in the region. However, critics argue that 1950s Treaty has attempted to institutionalize India's strategic hegemony over Nepal's foreign trade policy. In their study, Dabhade \& Pant (2004) opine that Indians want to control the breadth and depth of Sino-Nepal relation. This indicates that the 1950s treaty, in the name of peace and friendship, has been functioning as clearly Indian politics for Nepalese economy.

From Sugauli Treaty 1950 to the present, many bilateral and mutual cooperation, facilities and promotion have been increased (Paudel \& Devkota, 2018). On the basis of King Mahendra's initiation to diverse foreign policy in 1955 (Nayak, 2010), Nepal's diplomatic relationships were established between China and Nepal on August 1955 (Dhabade \& Pant, 2004) along with economic liberalization, trade liberalization and policy reforms, encouragement of private sector participation in economic development, foreign account convertibility in 1980s. To strengthen further foreign trade relation, Nepal has been the member of WTO in 2004. Even though Nepal deserves fundamental transit rights from India, trade and transit regulations are performed by bilateral trade only. As a result, Nepal is facing serious trade deficit. Its impact has directly observed in small scale business in cross-border Nepalese trade and businesses.

Though open border has facilitated strong and unique bilateral relation there are many irritants and problems of serious concerns between two nations like territorial disputes and encroachment. Researchers believe that misused by smugglers, drugs and arms traffickers, terrorist and insurgence, petty criminals as well as residual points of disputes along the border have strained the relationship (Das, 2008). Further, Das (2008) mentions that there are 54 territorial disputes. Nayak (2010) also explains that there are some irritants between the two countries and transit trade is one of them. The major reason behind these

1 The East India Company, also known as the Honourable East India Company or the British East India Company and informally as John Company, was an English and later British joint-stock company. It was formed to trade in the Indian Ocean region (Lawson, 1993). 
disputes can be seen as border linkage. There are 22 land border points ${ }^{2}$ specified as agreed routes for Nepal-India bilateral trade and transit (Pohit, 2016). Unfortunately, most of the main bilateral routes pass through Bihar $^{3}$ (Pohit, 2016) where roads are in poor condition and limits the speed of vehicles up to 20 $\mathrm{kph}$ and also check posts may take upto 8 hours to negotiate (Pohit, 2008). As a result, most of the time perishable fruits and vegetables reach to Nepalese market rotten and leads to loss of huge investment of Nepalese traders. In other side, china requires entry and exit visa in the cross flow of people from border, it has obstructed cross-border purchase, unlike India (Paudel \& Devkota, 2018). Further, major bottlenecks identified by different researchers and intellectuals in bilateral mechanism between Nepal and India border are restricted transit trade movements, cumbersome custom clearance process, delay in loading and unloading, limited warehouse facilities, poor road conditions, physical and manual process, delay in road transportation and railways, single sea port facilities, pilferage of good during transit, political tussles in both sides of the bordering region, politics behind the third-world trade relations. Apart from these bottlenecks, big brother feelings and dominations, biasness, ... etc. are the other hurdles (Nayak, 2010). Hence, unless such hurdles have been resolved, small nation like Nepal suffers with multiple procedural complexities that result in huge indirect cost than the direct benefits. These indirect cost can be specified as temporary shortage of commodities in local market, price hike, time loss, loss of opportunity cost and apathetic feelings in entrepreneurship.

Nepal is often viewed as buffer state between India and China which indicates Nepal is area for India-China strategic rivalry (McDonald \& Vaughn, 2013). India has been a major facilitators in Nepal's economic development that contributes $40 \%$ of the Nepal's direct investment and the largest trading partner (Nayak, 2010). But, Adhikari (2014) mentions that Nepal's economic dependence on India for overseas trade and transit has been used by the India to pursue political objectives. However, India has been creating problems in Nepal's third country trade with an additional-one-time lock system and other restrictive provision in the treaty (Nayak, 2010). Pattanaik (1998) also claims that the open border has resulted in a demographic threat to a small nation like Nepal. Similarly, Kathmandu based intellectuals believe that India has not been flexible enough on transit issues (Nayak, 2010). In this situation, Nepal's foreign policies in relation to border should be visionary and it should not be affected by changes in the governments.

In South Asia, the borders of most of the countries are penetrable due to overlapping cultural bond within which Indo-Nepal socio-cultural intercourse has remained indispensible (Pattanaik, 1998). In the trade deficit and lack of development, Blair (2018) prescribes Nepal to follow the Bihar, India as a model for progress in terms of identity, dignity and development. However, he has exaggerated the dalit and marginalization population of Nepalese Terai and has stimulated with biasness. The misconception rumor like Nepal is safe heaven for terrorists, smuggler, anti-Indian elements sponsored by Pakistan and Chinese Intelligence in a way or another plays some roles to increase cross-border tussle which creates adverse impact on small business. Similarly, Nepal has benefited from the conflict between China and India; it has played the "Chinese Card" effectively as a bargaining tool against India. Such blames are one-sided and just to make neighboring nations under pressure that harm the existing business. Nepalese economy has been doing well due to its economic linkages with the growing economy of India. It is not matter of costbenefit analysis when the issue is related to social harmonization. Thus, though Nepal-India shares intense

\footnotetext{
${ }^{2}$ Out of the 22 land border points 15 of the border points have also been specified for Nepal's third country import-export (Pohit, 2016).

${ }^{3}$ Bihar is an east India State bordering Nepal (Choudhary \& Ghosh, 2015)
} 
people-to-people relation, Nepal government should be able to take strong stand in the case of protecting sovernity and minimizing trade deficit.

\section{METHODOLOGY}

This study has been prepared using a mixed method of analysis, considering the border business scope, content analysis was done by reviewing past studies on the topic, reviewing border related documents and reports from various sources and also reviewing studies and grey literature as available from a thorough internet search. To get a larger picture of the study, the researchers have drawn secondary information from past to the recent border related publications exhaustively available. Primary data related information was retained based on the previous cross-sectional researches on the customers side with 429 respondents (Paudel et al., 2018) and 372 small business owners (Paudel \& Devkota, 2018). Thus, this paper dominantly bases on descriptive methodology and desk review.

\section{EMPIRICAL RESULTS AND DISCUSSION}

\subsection{Customers' perspectives in Nepal-India cross-border small business}

Migration between India and Nepal has been easy due to an open, porous border and strong family link (Behera, 2011). So, people in the border area have their close ties to the people in the other side of the border. The greater the relation, easier it is to run the businesses. Das (2008) mentions that there are three types of movements from Nepal to India. The first type is to buy the daily goods, the second can be taken as the seasonal migrants and the third ones generally settle down for the long term basis. Similar movement occurs from India to Nepal. Pattanaik (1998) mentions that Indian immigrants to Nepal are engaged in urban and industrial sectors. At present, Indians migrants can be observed in Nepal from barber shop to parliamentary representation. It indicates population movement across the international boundary has even wider ramifications (Pattanaik, 1998). Especially, in an open border sharing countries including Nepal and India, such consequences are bigger.

Shopping in border areas is a common activity in many parts of the world (Azmi et al., 2015). Language and cultural factors help to spread business. Language and cultural socialization profoundly influence how people see themselves and communicate with other people having different backgrounds (Jackson, 2014). Many people from the both nations have utilized open border for service, business and attainment of facilities (Paudel et al., 2018). Further, Paudel et al. (2018) argue that there is a very long evidence of purchasing goods across the Sunauli, Nepal-India border i.e. over six decades. They observe that good information about market, hassle-free border movements, communication access in the border region are the important influencing aspects for cross border purchase (Schack, 1999; Setnikar et al., 2014). Hence, Szytniewski et al. (2017) rightly remarks that feelings of proximity and distance are sensed rather than known, especially in the performance of peoples' movement for cross border purchase. Houtum (2000) believes that effective level of communication makes purchase much better in border area. Therefore, to protect cross border purchase, emphasis should be given to perception of the people, harmony, trust and international brotherhood (Paudel et al., 2018). From the policy perspectives, shopping in particular is important issue for developing new strategies and for further strengthening crossborder cohesion and regional attachment (Szytniewski et al., 2017).

In the border area, customers' movements increase in the festivals in which languages, customs and practices also influence for cross border purchase (Székely, 2013; Setnikar et al., 2014 and Paudel et al., 2018). Such relations enhance and expand cross-border business and affect socio-cultural transformation. 
However, Nepalese customers are accustomed to purchase across border not only due to economical price of the commodities but also due to commonalities in the socio-cultural aspects more than in China as (Hogg, 2007) claims through a non-negotiable, unilateral agreement on the free movement of goods and people between the two countries, India gives Nepal Duty-free access to all agricultural and industrial exports. Finally, to attract non-local costumers, respondents opine that some of the activities like offering quality product, reasonable price, better service, good behavior, healthy and friendly relation, proper communication and attractive advertisements also play positive roles.

Communication in border area is another important influencing aspect for cross-border purchase (Schack, 1999; Setnikar et al., 2014). Effective level of communication makes purchase much better in border area (Houtum et al., 2000). The link between Information and Communication Technology (ICT) and International Business is relatively recent and continually growing aspect (Chelariu \& Osmonbekov, 2014). Poudel et al. (2018) also have found that easy access to communication has helped customers to improve their purchase. Similarly, ICTs can help to make cross-border judicial procedures more transparent, efficient and economic both in civil and criminal matters (Pangalos et al., 2014). So, in the growing roles of ICTs worldwide, cross-border connectivity and infrastructure development must incorporate ICTs in Nepal-India border business activities. It helps to exchange biometric records, manage cross-border small business activities, control tax invasions, terriorist involvements and border agitations.

Thus, one important insight for open border small business activities is to understand customers' perspectives regarding their cross-border purchase and the socio-economic and cultural factors behind it. The recent paper from Paudel et al. (2018) reveals that in Nepal-India border, socio-cultural, geopolitical and economic proximities contribute customers to involve in cross border purchase activities. Further, they observe that border customers mostly purchase the goods for the daily households needs and majority of the people (i.e. 85.6\%) involve in cross-border purchase due to economical price of the goods followed by festivals $(77.2 \%)$, cultural homogeneity $(71.6 \%)$, communication access $(71.2 \%)$ and habit $(54.6 \%)$.

So, cross-border activities are increasing due to various beneficial motives such as easy entrance through borders, economical price of the commodities, easy purchase-sell activities, common and understandable language, cultural similarities, family relation across the border and trust (Jha, 2013). Regarding easy access to import and export goods in the boarder, there is mixed response $-53 \%$ of the total respondents argue that border access is easy for them to import goods while other $47 \%$ respondents state that it is difficult to export and import goods. Hence, as Stojkov \& Nikolov (2008) mention that without strengthening cultural cross-border relation, it is impossible to build strong links and cooperation between neighboring nations. In case of Nepal-India border business too, government should take initiatives for systematizing cross-flow to strengthen small business activities.

\subsection{Business owners' perspectives in Nepal India cross-border small business}

In the context of bordering nations cross border cooperation applies equally to the activities of local authorities at various levels as well as to joint initiatives, e.g. non-governmental organization for business (Kurowska-Pysz, 2016). The rapid urbanization has opened up economic opportunities for the inhabitants of both sides' border regions (Das, 2008). Over the centuries the unrestricted movement of people across the border has led to the development of well entrenched socio-cultural linkage between the people of the two countries have facilitated greater economic independence and political ties (Das, 2008). Thus, Setnikar et al. (2014) rightly remarks that cross border cooperation is becoming an increasingly important factor in establishing a stimulating business environment that includes different levels of cooperation between 
regions and neighboring states. Paudel \& Devkota (2018) mention that in Nepal-India open-border region many factors affect business today than 30 years before. Such factors include nature and price of goods, taste and preference of customers, growing publicity of business, change in business and border rules, growing technology and development of infrastructure have changeed massively and led positive influence on current Nepal-India border side business (Paudel \& Devkota, 2018). Also they observe that living standard of the entrepreneurs has increased from their business, which they consider as the most important source of their family survival in promoting their socio-economic status.

Apart from urbanization, many other reasons have grown Indian merchants' interest in Nepal's growing consumer market (Das, 2008). Lack of industrialization in India provides Indian businessman with incentives to open new venture in Terai, Nepal (Pattanaik, 1998). As a result, Indian merchants and entrepreneurs have invested heavily in Nepal. The important part is that setting up business in Nepalese Terai offers cheaper labor and tax breaks for Indian businessman (Das, 2008). Today, about 256 approved Indian joint ventures have been established and making business in Nepal (Das, 2008). Such Indian entrepreneurship has been displaced local and small scale enterprises in Nepal.

Though lots of progress has been observed in border area business, the extent of informal trade between Nepal and India is less explored especially in locally produced goods (Hogg, 2007). Several studies including Ayadi et al. (2013), Golub \& Mbaye (2009), Golub (2012) and Bensassi et al. (2016) observe the level of informal trade in cross-border region and have found goods smuggled as the major problem in cross-border small scale activities. Fuest and Riedel (2010) argue that revenue loss in cross border activities stemming from tax evasion activities is the smuggling of goods across border as a way of evading tax and other forms of indirect taxes including customs and excise duty.

Some of the major bottlenecks of Nepalese small scale business in border area comprise the restriction imposed by bordering Indian provinces on Nepalese origin products (Nayak, 2010). Beyond the product restriction, Nepalese exporters have also faced certification of standard hurdle. Often the Indian customs send samples to their labs for testing that usually remains against the spirit of India-Nepal treaty (Nayak, 2010). As a result, cargo movement is held up and sometimes damaged if it is a perishable item (Pohit, 2016). Also, Nepalese exporters are continuously harassed by Indian customs and security personnel for Nepali Items treating as foreign components. It is against the bilateral relational treaty (Nayak, 2010). Such bottlenecks of Nepalese trade have led trade deficit. Further, other major causes of Nepalese trade deficit are informal trade, high tariffs and non-tariffs barriers, domestic policy distortion, weak infrastructure and illegal trade. To resolve these issues, central level dialogues should play the vital roles and the decisions of such dialogues must be circulated in the border administrations for execution.

To sustain cross-border entrepreneurship Paudel \& Devkota (2018) highlight the requirements to increase in cooperation, facilitation for cross border purchase, enhancement of appropriate market information and communication, proper regulation and monitoring at border point in strengthening and enhancing healthy cross-border small scale business performance. Year(s) of business operation, family and business residing the other side of the border, annual income from the business, tax-evasion goods and use of agents to import goods substantially affect small business performance in open border region. Therefore, open border requires increase in cooperation, facilitation for cross border purchase, enhancement of appropriate market information and communication, proper regulation and monitoring at border point in strengthening and enhancing healthy cross-border small scale business performance.

\subsection{Discussion on cross border small business perspectives}

Nepal and India sustain bilateral relationship and share economic proximities contributing people of both nations to a number of advantages. The unrestricted movements of people across the border, over 
the centuries have led to the development of well-entrenched socio cultural linkages between the people of the two countries have facilitated greater economic interdependence and political ties between Nepal and India (Das, 2008). An open border has proved beneficial forging close economic interdependence and unique bilateral relation for both India and Nepal (Das, 2008). It shows that People's motivation in business is a multifactor and complex phenomenon of the contemporary society that is influenced by the system of values, commitments and perception of various people (Aliekperova, 2018). To institutionalize, equal rights in matter of residence, acquisition of property, employment and movement in each other territory are very important in the issue of Nepal and India (Das, 2008). Thus, border hurdles should be jointly solved to enhance cross-border purchase and to minimize the growing political agitation of the people for the sustainable small business. The key areas of fair bilateral coverage, co-existence, mutual respect and cross-border connectivity should be preserved in pursuit of progress and optimizing mutual benefits.

As the border points in Nepal-India are far from central governments, their importance in terms of socio-cultural, historical and economic aspects should not be neglected. Optimistically, (87\%) of the respondents in Paudel et al. (2018) contend that the -existing business can be systematized with law, strict border policy, less custom duty on goods while import and export, security in border and market area, friendly behavior with the customers, increasing stocks, maintenance infrastructure, selling quality goods, systematic management can be implemented to systematize the existing business.

Further, it reveals that there is significant relationship in cross-border purchase and small deviation in the peoples' daily activities and their perception towards goods, prices, relationship and other issues may affect their purchase badly and also could bring lethargic to the people who is purchasing and willing to purchase across the border. It is therefore necessary to systematize cross-border and small scale purchase in mutual interest and socio-cultural harmony.

Along with discussion, trade between Nepal-India is governed by numerous man made barriers (Pohit, 2016). Nepal's reservation to the treaty is based on the argument that the treaty compromises Nepal's ability to pursue an independent defense and foreign policy (Nayak, 2010) that affects in businesses. The Indo-Nepal open border has been a factor of interstate tensions, particularly, the issue of cross-border support to various internal conflicts inside the country (Pattanaik, 1998). Nepal has been wary of too close a relationship with China, afraid of antagonizing (Big Brother) India (Dabhade \& Pant, 2004). New Delhi imposed economic blockade in Nepal in March 1989 by closing down transit points that (It is repeated in 2013 in the name of Madesh movement) hamper a lot in cross-border activities (Dabhade \& Pant, 2004). In the available literature's discussion, it reveals that India uses the transit issue as a political leverage, Nepal claims excess to sea as its rights and without showing adequate sensitivity towards India's security concerns (Nayak, 2010). When Indian government is sensitive to security issue from Nepal, Nepalese feel threat to the identity of their nation from Indians (Pattanaik, 1998). India has desired to maximize Indian influence in Nepal, particularly in Terai, where the border transit resides (McDonald and Vaughn, 2013). However, the direct role of the other nations and institutional effort in helping Nepal has been more limited compared to the influence of India in aids and trade.

It is clear that countries that still lag behind are those, which are still afflicted in the quicksand of political instability and unclear economic policies. Corrupt politicians, beaurocrats and businessmen who manipulate laws, rules and regulations for massive commissions as personal gains has become one of the key reasons for the difficulties of smooth regulation of policies and ultimately the underdevelopment of the nations. Discouraging entrepreneurships, blind eyes to tax-evasion goods, clouded business environment, lack of clear policy, imposed tax, lack of security and protection, political unions and vicious cycle of corruptions, hasslesome administrative procedures and biased regulations have harassed the system and entrepreneurial growth even in the borders of Nepal-India. To summarize, the emphasis of 
Nepal-India small business activities should be based on perception of the people, harmony, trust, trade relation and international brotherhood for the growth and systematization of small business.

\section{CONCLUSION}

Open border is beneficial in Nepal-India relation with economic interdependencies, however, policy of non-alignment and equi-distant relations are vital for Nepal in Nepal-India relations. Both the nations have federal democratic political system in mixed economy regulations. But in the case of small business in border areas, India and Nepal have not been able to adequately address and harmonize till the date. This research emerges after comprehensive cross-sectional analysis from both customers and entrepreneurs' perspectives on small businesses of Nepal-India border along with available literature and existing laws, and then the research derives the following policy implications worth considering:

1. Small business connection in Nepal-India trade relation: Open border in Nepal-India has created channel of trade, transit and investment. Nepalese overseas foreign trade is also depended with India. Goods imported from overseas are stuck to Indian ports. So, Nepal is more dependent to India on Trade. Indian authority should not take this as weakness of Nepal rather focus should be on cooperation and coalition building across differences and difficulties.

2. Cross-border connectivity and infrastructural development for business: $122^{\text {nd }}$ largest importer and 166 th largest exporter in the world, Nepal has to progress in economy by improving cross-border connectivity. To improve cross-border connectivity, the Indian government has decided to set up four integrated check posts (ICPs) at Raxaul, Sunauli, Jogbani and Nepalgunj. Equally, Nepal also should focus on its take in the issue for enhancing small businesses by improving the situation of cross border connectivity.

3. Exploiting ICTs in border administration: In the growing global use of technology and communication media, Nepal-India border also should enhance ICTs for accurate market information and to increase cross-border purchase. ICTs can make judicial procedures more transparent, control in criminal activities, build stronger business relation, ensure trust and harmonization, exchange biometric records to deter illegal activities, control tax-evasion goods and smuggling, and smooth operation of the cross-flow of goods and people.

4. Integration of people across Nepal-India border: Integration of border people into the national mainstream is important for developing stake in the border area development plans. This situation should be acknowledged from both sides as network enhancing policies for economic transformation. Inter-governmental committees can be formed to serve as means and medium of economic cooperation which can analyze the bottlenecks like restricted transit, cumbersome customs, procedural delays, warehouse problems, poor roads, pilferage of goods and single seaport facility to Nepali entrepreneurs.

5. Inter-state coordination in Nepal and internationalization of small business: In the changing political scenario of Nepal, all three layers of government: central, provincial and local should think about newly developed interstate small businesses and their internationalization for contributing national economy so that provincial government agreement possibilities with Indian sides, especially with Bihar and U.P., can be developed for harmonizing cross border small business. Even special economic zones can be developed in both sides of the nations.

6. Non-aligned and equi-distance policy adaptation from Nepal: Nepal's foreign trade policy including small businesses should not be formulated in the cost of China and India as istepiopposite binaries. Nepal government should practice a long-term strategy in small business border region policy that can be directed to a target, no matter the governments change frequently. Nepal 
should also be able to diversify its trade to foreign nations for sustainability and minimizing the risks, if the deals provide comparably the better opportunities than in India. Nepal should not sign more bilateral treaties and contracts only with India by freezing her better foreign opportunities.

7. Need of Comprehensive Further Research from Nepal: Nepali researchers in Nepal- India open border study possess weaknesses that they hesitate to provide actual and critical solutions in border problems, even in their rarely pointed out issues. Little research has been done so far on cross-border from Nepal side that has to be increased in production of new knowledge, especially in harmonizing small business. Nepal has to allocate Research and Development funding for continuous economic innovation and upgrading of knowledge in the pursuit of economic progress. Thus, Nepal and India need to conduct extensive consultation to achieve mutual growth rather than imposing one's position on other.

8. Springboard for Small Scale Business Opportunities: Though borders are complex human constructs, the Nepal-India open border should be taken as dynamic concept in which the further study should be focused on interdependence and springboard for opportunities and potential possibilities rather than widening rifts and ridges of business deficit. What needs to be emphasized is the prosperity and well being of the people in both the nations.

9. Institutionalizing Win-win Small Scale Business Prospects: Border should not be closed for any reasons as it affects the economic prospects of both the nation. Indian side should not impose frequent border blockades as weapons for certain political gain. The focus should be on how to systematize rather than how to take more benefit. Though India is the largest trading partner of Nepal and trade statistics reveal phenomenal increase in the size of the business; trade deficit is continuously widening. Thus, open border should be harnessed as win-win cooperation is only choice for Nepal and India.

In a nutshell, Nepal-India cross border small businesses should not be guided by emotions and sentiments rather concrete policy should be developed generating futuristic decisions by re-visiting the policy repertoire. In the case, partnership can be the most valuable asset through which Nepal and India can look beyond the horizon for steering their economy in the right direction. The small businesses should not be nullified as they contribute significantly to national economy and development. Hence, the small businesses in cross-border regions of Nepal-India should be sustained, systematized and harmonized by integrating people in border regions following people centered approaches.

\section{REFERENCES}

Adhikari, R.R. (2015). Promoting Nepalese trade and investment relation with India and China/Ministry of Foreign Affairs edited by Rishi Raj Adhikari. Kathmandu: Institute of Foreign Affairs.

Adhikari, M. (2014). Politics and perceptions of Indian aid to Nepal. Strategic Analysis, 38(3), 325-340.

Afrika, J. G., \& Ajumbo, G. (2012). Informal cross border trade in Africa: Implications and policy recommendations. Africa Economic Brief, 3(10), 1-13.

Aliekperova, N. (2018). Motivating factors effecting work efficiency of employees in Ukrainian pharmaceutical sector. Economics \& Sociology, 11(1), 61-74.

Andersen, T. J., \& Foss, N. J. (2005). Strategic opportunity and economic performance in multinational enterprises: The role and effects of information and communication technology. Journal of International Management, 11(2), 293-310.

Anderson, J., \& Wever, E. (2003). Borders, border regions and economic integration: one world, ready or not. Journal of Borderlands Studies, 18(1), 27-38. 
Ayadi, L., Benjamin, N., Bensassi, S., \& Raballand, G. (2013). Estimating informal trade across Tunisia's land borders. The World Bank.

Azmi, A., Hamid, I. A., Ahmad, J. A., \& Ramli, R. A. (2017). Tourism supply chain perspectives on border shopping development at Padang Besar, Malaysia. In Balancing development and sustainability in tourism destinations (pp. 291300). Springer, Singapore.

Azmi, A., Sulaiman, S., Asri, D. A. M., \& Razali, M. A. (2015). Shopping tourism and trading activities at the border town of Malaysia-Thailand: A case study in Padang Besar. International Academic Research Journal of Social Science, 1(2), 2015.

Baral, L.R. (1992) India-Nepal Relations: Continuity and Change. Asian Survey , 32, 815-829. https://doi.org/10.2307/2645073

Behera, S. (2011) Trans-Border Identities: A Study on the Impact of Bangladeshi and Nepali Migration to India. ICRIER Policy Series , 1, 1-31.

Bensassi, S., Jarreau, J., \& Mitaritonna, C. (2016). Determinants of Cross Border Informal Trade: the case of Benin. Washington DC: International Food Policy Research Institute (IFPRI), AGRODEP Working Paper, 34.

Blair, H. (2018). Identity, dignity and development as trajectory: Bihar as a model for democratic progress in Nepal? Part II. Nepal's promise. Commonwealth \& Comparative Politics, 56(2), 216-233.

Boellis, A., Mariotti, S., Minichilli, A., \& Piscitello, L. (2016). Family involvement and firms' establishment mode choice in foreign markets. Journal of International Business Studies, 47(8), 929-950.

Chelariu, C., \& Osmonbekov, T. (2014). Communication technology in international business-to-business relationships. Journal of Business \& Industrial Marketing, 29(1), 24-33.

Choudhary, N., \& Ghosh, A. (2015). Indo-Nepal economic cooperation: a subregional perspective. Asia-Pacific Development Journal, 21(2), 23-52.

Covarrubias, D. (2017). Analyzing how a Social Base Impacts Economic Development and Competitiveness Strategies in a Cross-border Context: the Case of Region Laredo. Journal of Borderlands Studies, 1-20. https://doi.org/10.1080/08865655.2016.1270168

Dabhade, M., \& Pant, H. V. (2004). Coping with challenges to sovereignty: Sino-Indian rivalry and Nepal's foreign policy. Contemporary South Asia, 13(2), 157-169.

Das, P. (2008). Towards a regulated Indo-Nepal border. Strategic Analysis, 32(5), 879-900.

Davis, S. J., Faberman, R. J., \& Haltiwanger, J. (2006). The flow approach to labor markets: New data sources and micro-macro links. Journal of Economic perspectives, 20(3), 3-26. DOI: 10.3386/w12167

Decoville, A., \& Durand, F. (2018). Exploring cross-border integration in Europe: How do populations cross borders and perceive their neighbours?. European Urban and Regional Studies, 0969776418756934. https://doi.org/10.1177/0969776418756934

Dutta, P. (2010). India-Bangladesh Relations-Issues, Problems and Recent Developments. Special report. New Delbi: Institute of Peace and Conflict Studies.

Fuest, C. and Riedel, N. (2010).Tax Evasion and Tax Avoidance in Developing Countries: The Role of International Profit Shifting (Oxford: Oxford University Centre for Business Taxation), Working Paper 1012.

Golub, S. S. (2012). Entrepot trade and smuggling in West Africa: Benin, Togo and Nigeria. The World Economy, 35(9), 1139-1161.

Golub, S. S., \& Mbaye, A. A. (2009). National Trade Policies and smuggling in Africa: the case of the Gambia and Senegal. World Development, 37(3), 595-606.

Hogg, C. L. (2007). India and its Neighbours: Do Economic Interests have the Potential to Build Peace? Chatham House Report (October). London: Royal Institute of Interna- tional Affairs.

Houtum, V. H. (2000). III European perspectives on borderlands: an overview of European geographical research on borders and border regions. Journal of Borderlands studies, 15(1), 56-83. https://doi.org/10.1080/08865655.2000.9695542

Jackson, J. (2014). Introducing Language and Intercultural Communication. New York: Routledge.

Jha, H.B. (2013) Nepal's border relations with India and China. Eurasia Border Review, 4, 63-75.

Johanson, J., \& Vahlne, J. E. (1990). The mechanism of internationalisation. International marketing review, 7(4), 11-24. 
Kansakar, V.B.S. (2001) Nepal-India open borders: Prospects, problems and challenges. Series of Seminars, the Institute of Foreign Affairs and FES, Nepalgunj, Birgunj, Biratnagar and Kathmandu.

Kavitha, K. K. (2016). The Changing Paradigm of India- Nepal Relations: Problems and Prospects. Journal of Research in Business and Management, 4(5), 10-15.

Kolk, A., \& Margineantu, A. (2009). Globalisation/regionalisation of accounting firms and their sustainability services. International Marketing Review, 26(4/5), 396-410.

Kot, S., Meyer, N., \& Broniszewska, A. (2016). A Cross-Country Comparison of the Characteristics of Polish and South African Women Entrepreneurs. Economics \& Sociology, 9(4), 207-221.

Kramer, X. (2011). Cross-border enforcement in the EU: mutual trust versus fair trial? Towards principles of European civil procedure. International Journal of Procedural Law, 2, 202-230.

Kuépié, M., Tenikue, M., \& Walther, O. J. (2016). Social networks and small business performance in West African border regions. Oxford Development Studies, 44(2), 202-219.

Kumar, R. (2013). India-Nepal Open Border: Springboard for Opportunities. International Studies, 50(1-2), 165-183.

Kurowska-Pysz, J. (2016). Opportunities for cross-border entrepreneurship development in a cluster model exemplified by the Polish-Czech border region. Sustainability, 8(3), 230, 1-21.

Kuzmin, O., \& Kravchenko, I. (2014). Cross-border cooperation of enterprises: essence and significance. ECONTECHMOD: An International Quarterly Journal on Economics of Technology and Modelling Processes, 3(2), 35-40.

Lawson, P. (1993). The East India Company: A History. London: Longman.

Lesser, C. and E. Moisé-Leeman. (2009). Informal Cross-Border Trade and Trade Facilitation Reform in SubSaharan Africa, OECD Trade Policy Papers, No. 86, OECD Publishing, Paris. https://doi.org/10.1787/225770164564.

Liao, T. F. (1994). Interpreting Probability Models: Logit, Probit, and other Generalized Linear Models. Thousand Oaks, CA: SAGE Publications, Inc.

Macamo, J. L. (1999). Estimates of unrecorded cross-border trade between Mozambique and her neighbors. Office of Sustainable Development, Bureau for Africa, USAID, Washington, DC, Technical Paper, (88).

McDonald, S. M., \& Vaughn, B. (2013). Autonomy in the Southern Borderland of Nepal: A Formula for Security or Cause of Conflict?. Journal of Borderlands Studies, 28(2), 153-168.

Minde, I. J., \& Nakhumwa, T. O. (1998). Unrecorded cross-border trade between Malawi and neighboring countries. Office of Sustainable Development, Bureau for Africa, US Agency for International Development.

Nayak, N. (2010). India-Nepal Peace and Friendship Treaty (1950): Does it Require Revision?. Strategic Analysis, 34(4), 579-593.

Ogalo, V. (2010). Informal cross-border trade in EAC: Implications for regional integration and development. Research Paper: CUTS Geneva Resource Centre.

Pangalos G, Salmatzidis I, Pagkalos I (2014) Using IT to provide easier access to cross-border legal procedures for citizens and legal professionals - implementation of a European payment order E-CODEX pilot. Int J Court Adm, 6(2), 43-52.

Pant, Y. P. (1962). Nepal-India Trade Relations Some Recent Trends. https://www.epw.in/system/files/pdf/1962_14/8/nepalindia_trade_relationssome_recent_trends.pdf

Pattanaik, S. S. (1998). Indo-Nepal open border: Implications for bilateral relations and security. Strategic Analysis, 22(3), 461-478.

Paudel, U. R. \& Devkota, N. (2018). Socio-economic influences on small business performance in Nepal/India open border: Evidence from Cross-sectional Analysis. Economics and Sociology, 18(4), 11-30.

Paudel, U. R., Devkota, N., \& Bhandari, U. (2018). Socio-Cultural and Economic Factors in Cross-Border Purchase: A Study of Customers' Perspective in Sunauli-Nepal/India Border. Modern Economy, 9(6), 1089-1102.

Paudyal, G. (2014). Border Dispute between Nepal and India. Researcher: A Research Journal of Culture and Society, 1(2), $35-48$.

Pohit, S. (2018). Quantifying impediments to India-Nepal overland trade: Logistics issues and policy message. Journal of Borderlands Studies, 33(4), 569-584.

Reisinger, Y. (2009). International Tourism: Culture and Behaviors. Oxford: Betterworth. 
Schack, Michael (1999). On the Multi-contextual Character of Border Regions, 39th Congress of the European Regional Science Association. Regional Cohesion and Competitiveness in 21st Century Europe, August 23 27, 1999, Dublin, Ireland.

Scott, J. W. (1999). European and North American contexts for cross-border regionalism. Regional studies, 33(7), 605617.

Setnikar Cankar, S., Seljak, J., \& Petkovšek, V. (2014). Factors that influence cross-border cooperation between businesses in the Alps-Adriatic region. Economic research-Ekonomska istraživanja, 27(1), 304-319.

Sharma, S. and Thapa, D. (2013) Taken for Granted: Nepali migration to India. Centre for the Study of Labour and Mobility.

Shrestha, G. R. (2003). Nepal-India bilateral trade relations problems and prospects. Ministry of Finance, Nepal, 27.

Şlusarciuc, M. (2015). The Economic Potential of Crossborder Areas. Opportunities and Threats. Procedia Economics and Finance, 32, 801-808.

Stojkov, B., \& Nikolov, A. (2008). Cultural cross-border co-operation among Balkan's countries with the case of Serbia and Bulgaria. Glasnik Srpskog geografskog drustva, 88(2), 13-24.

Subedi, S. P. (1994). India-Nepal security relations and the 1950 treaty: time for new perspectives. Asian Survey, 34(3), 273-284.

Svensson, S. (2015). The bordered world of cross-border cooperation: the determinants of local government contact networks within Euroregions. Regional \& Federal Studies, 25(3), 277-295.

Székely, A. (2013). Border region structures. Analecta Technica Szegedinensia, 7(1-2), 64-70.

Szytniewski, B. B., Spierings, B., \& van der Velde, M. (2017). Socio-cultural proximity, daily life and shopping tourism in the Dutch-German border region. Tourism Geographies, 19(1), 63-77.

Tchouawou, M., Karugia, J., Mulei, L., \& Nyota, H. (2016). Assessing the participation of men and women in crossborder trade in agriculture: Evidence from selected East African countries.

Tkachenko, Y., \& Pustova, V. (2014). Approaches to the definition of cross-border cooperation: discussion points. The Russian Academic Journal, 29(3), 39-42.

Van der Velde, M., \& van Naerssen, T. (2011). People, borders, trajectories: an approach to cross-border mobility and immobility in and to the European Union. Area, 43(2), 218-224.

Velde, M. V.D. \& Van Houtum, H. (2003). Communicating borders. Journal of Borderlands Studies, 18(1), 1-11.

Walther, O. (2014). Border Markets: An Introduction. Articulo Journal of Urban Research, 10, https://articulo.revues.org/2532.

Williamson, O. E. (1975). Market and hierarchies: Antitrust implications, New York: The Free Press.

Williamson, O. E. (1979). Assessing vertical market restrictions: Antitrust ramifications of the transaction cost approach. University of Pennsylvania Law Review, 127(4), 953-993.

Williamson, O. E. (1981). The economics of organization: The transaction cost approach. American Journal of Sociology, 87(3), 548-577. 